\title{
Primary Glioblastoma of the Medulla Spinalis: A Report of Three Cases and Review of the Literature
}

\author{
Medulla Spinalis Kökenli GBM: Üç Olguluk Seri ve Literatürün Gözden \\ Geçirilmesi
}

\author{
Erkin OZGIRAY ${ }^{1}$, Ali AKAY ${ }^{1}$, Yesim ERTAN ${ }^{2}$, Sedat CAGLI $^{1}$, Nezih OKTAR ${ }^{1}$, Nurcan OZDAMAR ${ }^{1}$ \\ ${ }^{1}$ Ege University, Faculty of Medicine, Department of Neurosurgery, Izmir, Turkey \\ ${ }^{2}$ Ege University, Faculty of Medicine, Department of Pathology, Izmir, Turkey
}

Corresponding Author: Erkin OZGIRAY / E-mail: eozgiray@gmail.com

\begin{abstract}
Primary spinal glioblastoma multiforme (spinal GBM) is not a very common entity. This paper presents an outline of this rare neoplasm, its clinical presentation, course, management and outcome and reports a 3-case series of spinal GBM. In this 3-case series with spinal GBM, one of the patients was operated for hydrocephalous 10 months later following the tumor surgery and another patient had cerebral metastasis after the surgery. In the postoperative period, two of the cases received radiotherapy and one received combined radiotherapy and chemotherapy with steroid therapy together following the tumor surgery. The review of the pertinent literature has revealed that due to the scarcity of the reported cases of primary spinal GBMs, this issue requires a closer look. GBM behaves more aggressive in medulla spinalis than it behaves when it originates from cerebrum. It may disseminate to the cerebrum during its course and it may cause hydrocephalus due to this dissemination (metastasis).
\end{abstract}

KEYWORDS: Glioblastoma (GBM), Intramedullary, Spinal, Cerebral metastasis

öz

Primer spinal kökenli GBM (spinal GBM) çok yaygın bir patoloji değildir. Bu çalışma, nadir olarak görülen bu tümörün klinik sunumu, seyri, yönetimi ve sonuçlarını özetlerken, 3 olguluk bir spinal GBM serisini bildirmektedir. Bu spinal GBM'ye sahip 3 olguluk seride, olgulardan biri tumor cerrahisinden 10 ay sonra hidrosefali nedeniyle opere edilmiştir. Bir diğer olguda ise, cerrahi girişimi takiben serebral metastaz gözlenmiştir. Post-operatif süreçte, tumor cerrahi sonrası olgulardan 2'si radyoterapi ve diğer olgu da kombine radyoterapi ve steroid terapiyle birlikte kemoterapi almıştır. İlgili literatürün gözden geçirilmesi, rapor edilen primer spinal GBM’li olguların sayıca azlığı nedeniyle bu konunun daha yakından incelenmesinin gerekliliğini ortaya koymaktadır. Beyin kökenli GBM'ye kıyasla, omurilikte görülen GBM daha saldırgandır; gelişimi sırasında beyine doğru yayılabilir (metastaz) ve bu yayılma neticesinde hidrosefaliye yol açabilir.

ANAHTAR SÖZCÜKLER: Glioblastoma (GBM), İntramedüller, Spinal, Serebral metastaz

\section{INTRODUCTION}

Intramedullary tumors account for $16 \%$ of all spinal tumors, excluding metastatic lesions $(3,6,21)$. Although glioblastoma (GBM) is reported to account for more than $50 \%$ of primary cerebral tumor in adult patients, spinal glioblastoma multiforme is a less frequent entity, and accounts for only $1-5 \%$ of all glioblastomas and only $1.5 \%$ of all spinal cord tumors $(1,3,19,22)$. About $30 \%$ of spinal cord tumors are of low malignancy $(3,6,7,10)$. Malignant gliomas, i.e. glioblastoma multiforme (GBM), are less frequently described, with 7.5 $\%(3,6,7,12)$. The aim of this paper is to report three cases of spinal GBM, including one with intracranial seeding, and to discuss the clinical, radiologic and pathologic findings, operative techniques and adjunctive treatment of spinal GBMs with a review of the relevant literature.

\section{CASE REPORTS}

\section{No 1}

This 59-year-old man had a five-year history of low back pain. At admission, he had reported lower extremity pain. Neurological examination revealed left leg monoparesis and anesthesia to temperature, touch and pain at T1. Radiological evaluation showed an intramedullary tumor at T1 (Figure 1A-C). Gross total removal of the T1-T2 intramedullary tumor was performed. The histopathologic and immunochemical staining of the tumor tissue revealed the typical appearance of GBM (Figures 2-5). In the postoperative period, his neurological deficits were progressive, and the radiotherapy (total $27 \mathrm{~Gy}$ ) was planned. At his first radiotherapy treatment, he showed progressive neurological symptoms, i.e. loss of orientation. The patient could not receive the rest of the radiotherapy due to his neurological symptoms. Cranial CT showed brain stem infarction. He died 8 months after surgery. 

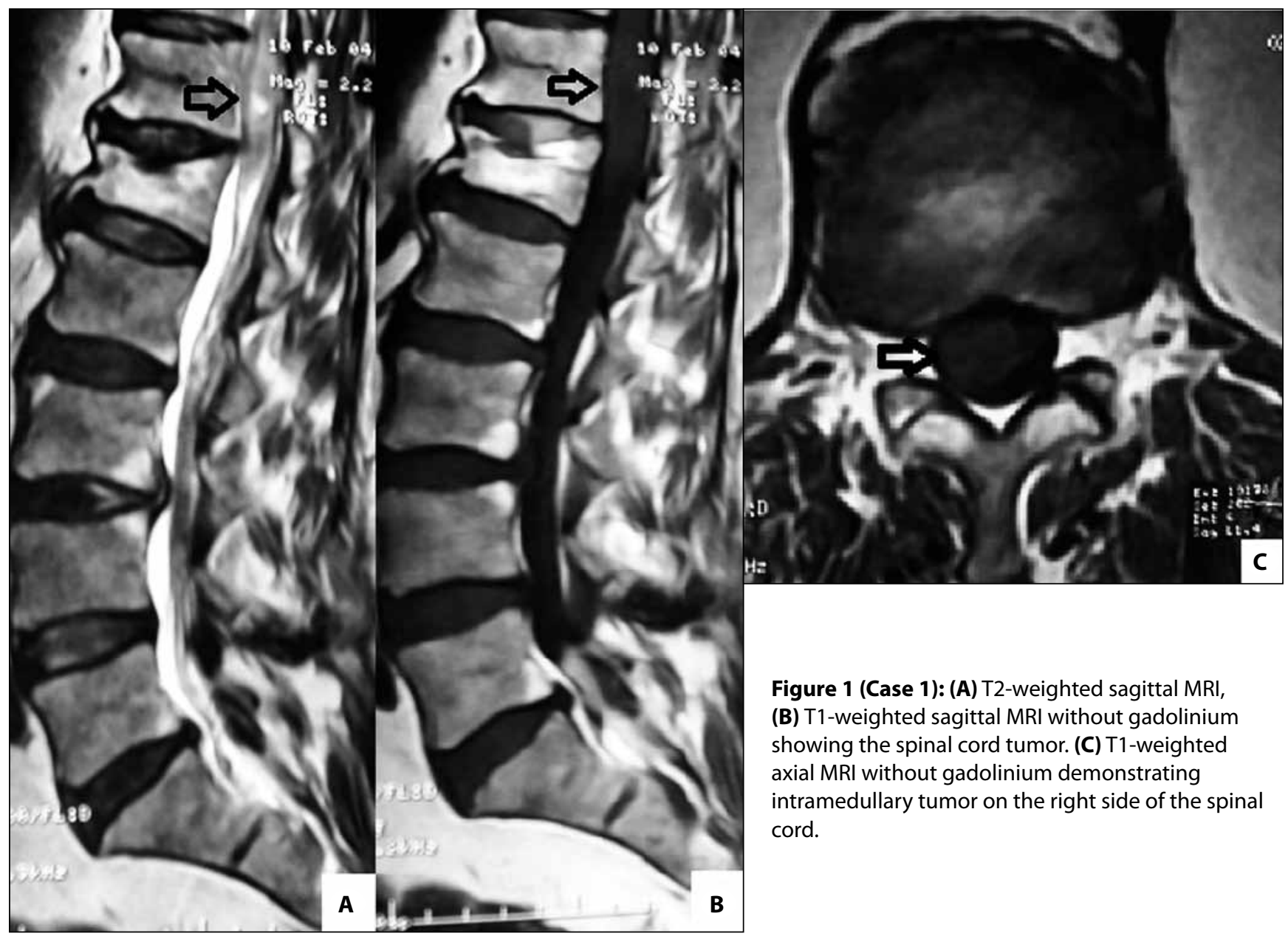

Figure 1 (Case 1): (A) T2-weighted sagittal MRI, (B) T1-weighted sagittal MRI without gadolinium showing the spinal cord tumor. (C) T1-weighted axial MRI without gadolinium demonstrating intramedullary tumor on the right side of the spinal cord.

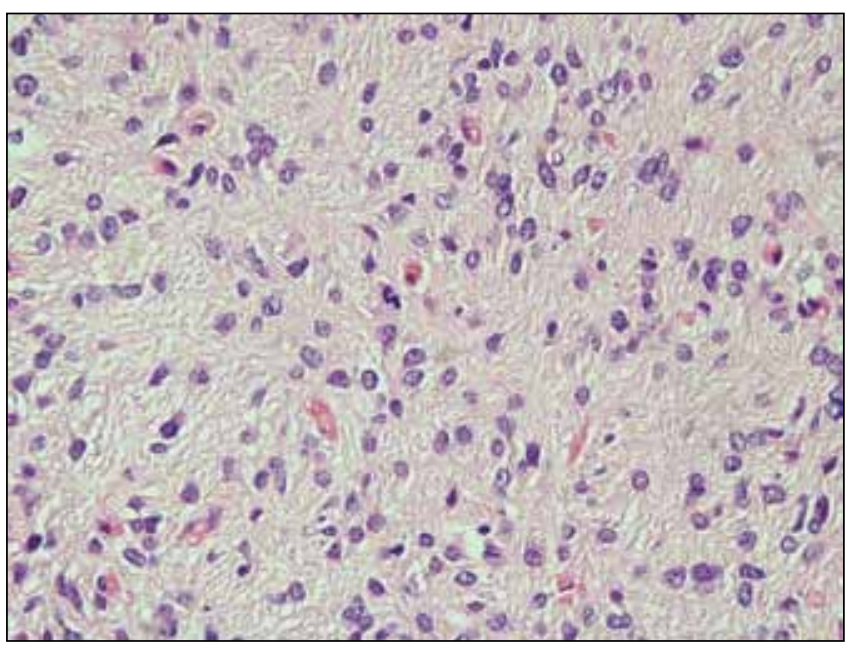

Figure 2 (Case 1): Highly cellular tumor composed of pleomorphic tumor cells, gemistocytes, mitosis and necrosis (Hematoxylin and eosinx200).

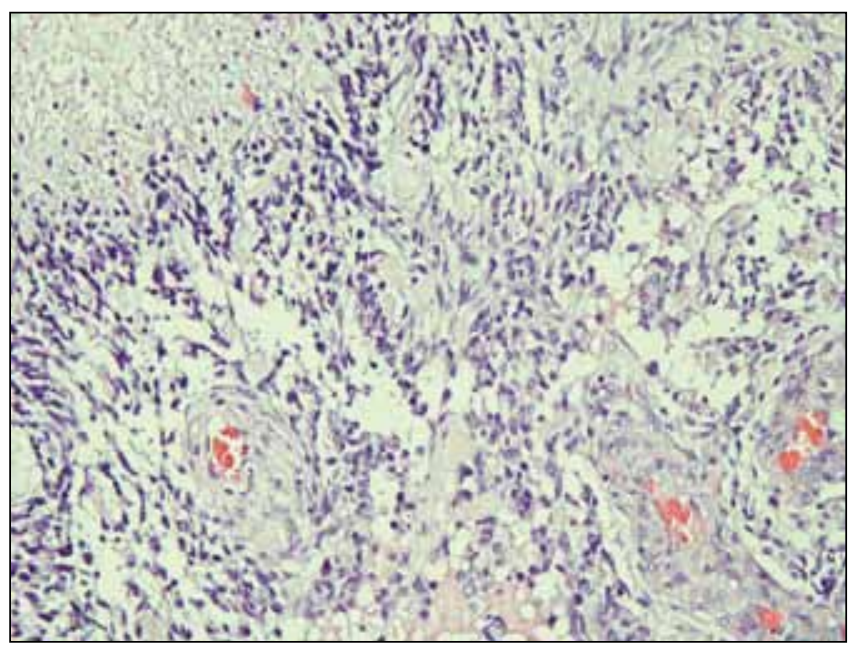

Figure 3 (Case 1): Nuclear MIB-1 immunoreactivity in tumor cells (x200). 


\section{No 2}

This 22-year old woman had back pain and right leg anesthesia. MRI presented a spinal tumor expanded to the cord with marked contrast (Figure 6A,B). Subtotal removal of the C5T2 spinal neoplasm was performed. The histopathologic and immunochemical staining revealed the typical appearance of a GBM (Figures 7-8). Postoperatively, the neurological deficits progressed. This patient received combined radiotherapy (36 Gy) and chemotherapy (temozolomide ) together following the surgical operation. 10 months later she was re-operated for hydrocephalous. The patient died 14 months after tumor surgery.

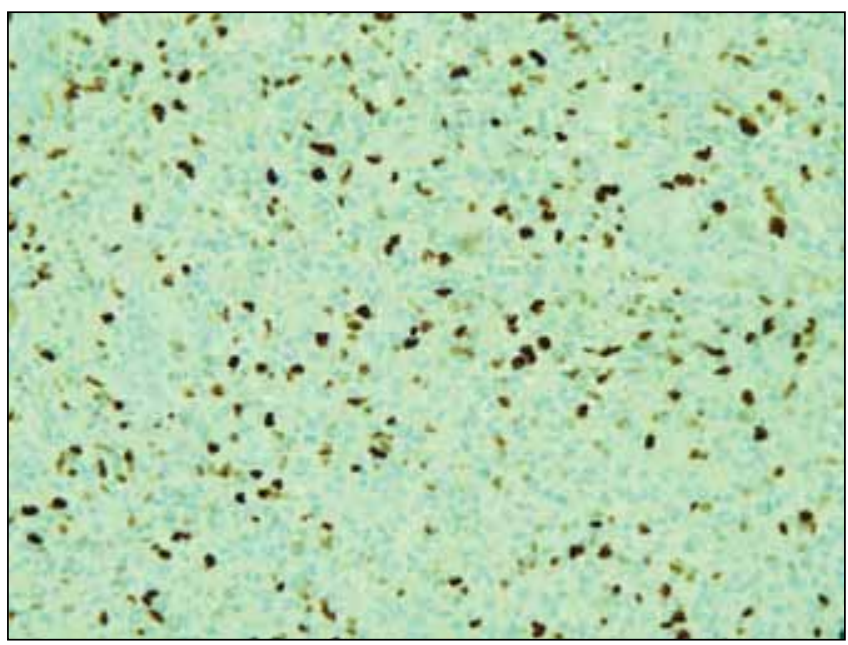

Figure 4 (Case 1): Nuclear MIB-1 immunoreactivity in tumor cells (x200).

\section{No 3}

This 54-year-old woman had suffered paresthesia for the last 2 months. Paresthesia has started in the cervical area and spread to both arms. Neurological examination revealed moderate quadriparesis and atacsia. Loss of vibration was present in the left extremities. Radiological evaluation depicted an intramedullary tumor at the C3-C4 level (Figure $9 A, B)$. Gross total removal of the C3-C4 was performed. The histopathologic and immunochemical staining showed a GBM. Postoperatively, neurological deficits progressed minimally. Planned radiotherapy was ceased after the first treatment due to worsening of the neurological status and weakness of general condition.

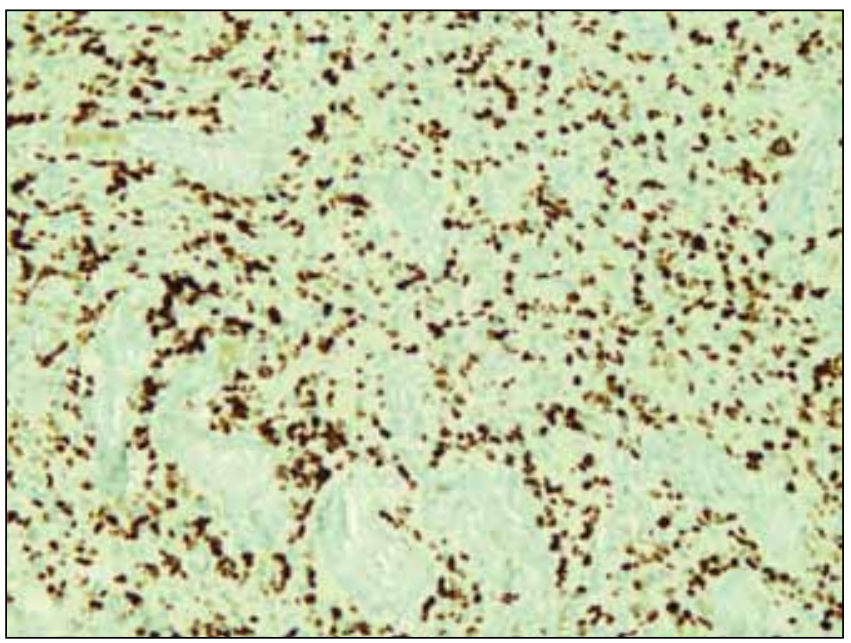

Figure 5 (Case 1): Nuclear p53 immunoreactivity in tumor cells (x200).

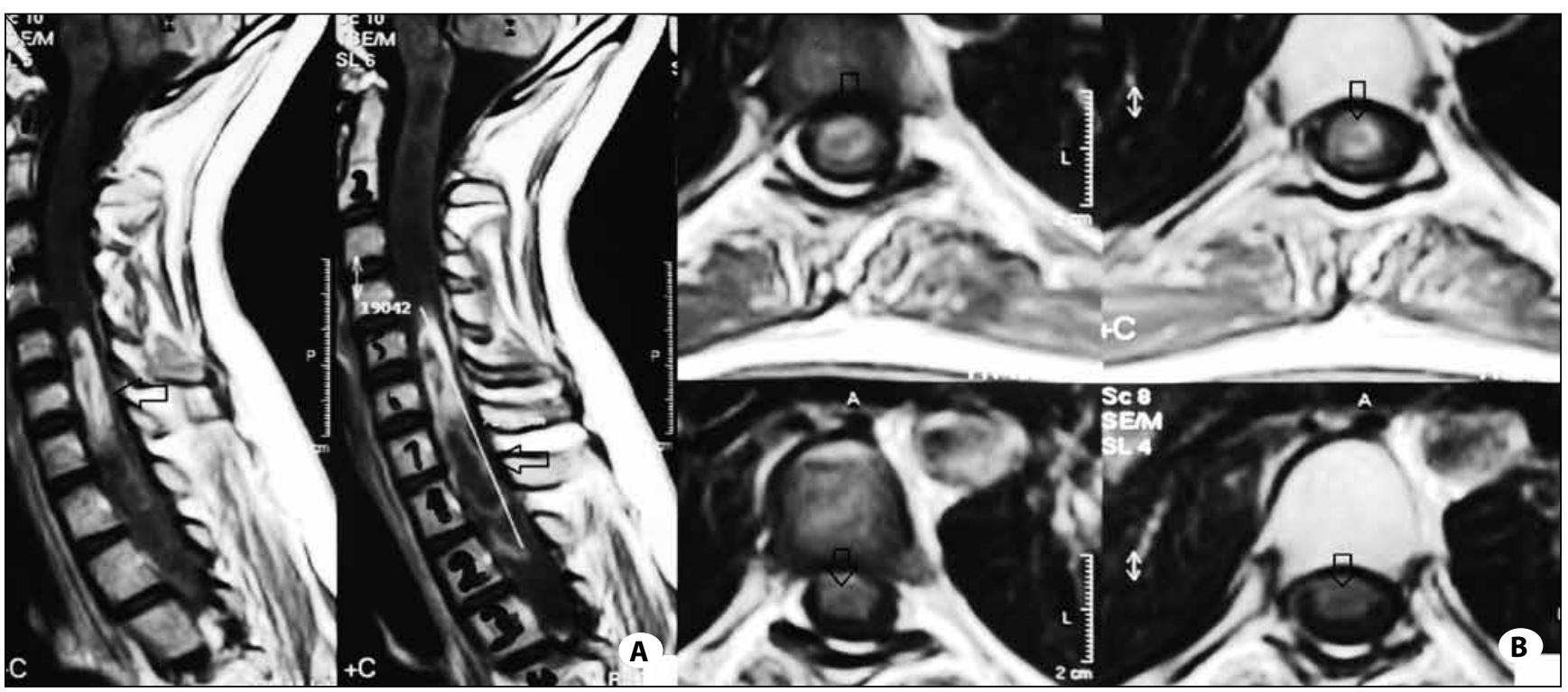

Figure 6 (Case 2): (A) T1-weighted cervical spine sagittal view MRI, enhanced with contrast, at presentation demonstrating a tumor (arrow). Tumor is beginning at C5 and ending at lower end of the vertebral body of T2. (B) T1-weighted cervical spine axial view MRI with contrast showing the intramedullary tumor (arrow). 
Four weeks later, during the post-operative routine control, she was suffering from diplopia and MRI showed extra axial cranial metastasis on SPA and meningeal seeding. This patient survived only ten weeks after the operation. This was the shortest survival among the three reported cases herein.

\section{RESULTS}

This small series consisted of one male and two female patients. The mean age of the patients was 44.4 years. In Case 1, the tumor was located in the thoracic region; in Case 2, in the cervico-thoracic region, in Case 3, in the cervical region. Signs and symptoms of intramedullary GBM's were related to tumor localization and consisted of pain, and motor sensory and autonomic deficits below the level of tumor. The patients in this series were evaluated between 2004 and 2007, so MRI was used for the diagnoses since it is still a gold standard technique for diagnosis.

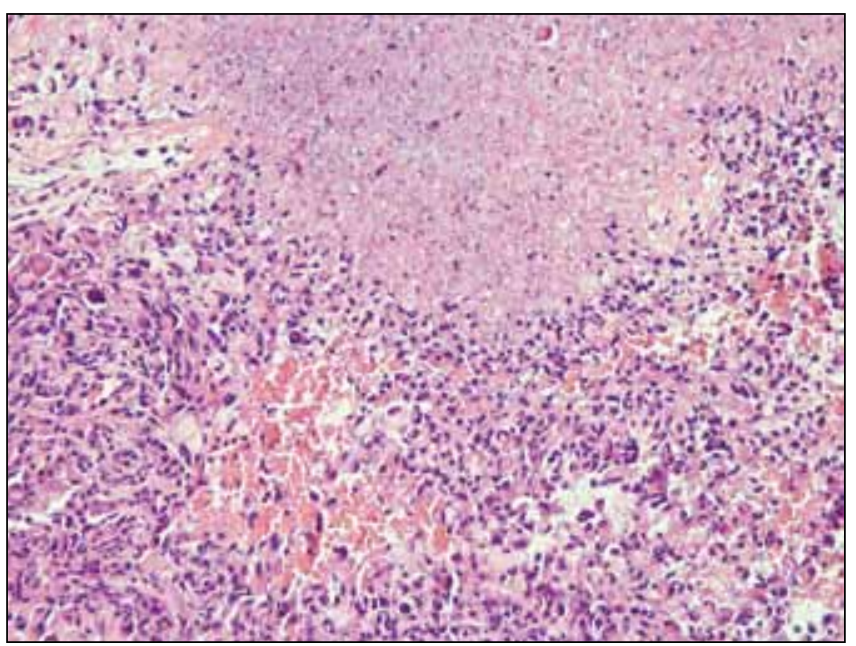

Figure 7 (Case 2): Pleomorphic tumor cells with fibrillary astrocytes and mitosis (Hematoxylin and eosinx200).
All the operations for tumor removal were performed via the posterior approach. During the operations, microsurgical equipment was employed and microsurgical principals were followed. Laminectomy was performed for Case 1 and Case 3; but laminotomy was preferred for Case 2 as the tumor was located at C5-T2 levels. Before the dural opening, the location of the lesion was confirmed precisely with the help of intraoperative ultrasonography. A midline myletomy was carried out and afterwards tumor removal was performed in all three cases. However, total tumor removal was not possible since there was no gliotic plane in any of the cases. For this reason, Cavitron Ultrasonic Surgical Aspirator (CUSA) was used to excise the tumors. A water-tight dural closure was applied to all of three patients. Any complications due to CSF leak were not observed. Dexamethasone was given prior to the surgery. After surgery was completed, the amount of dexamethasone given to the patients was reduced gradually.

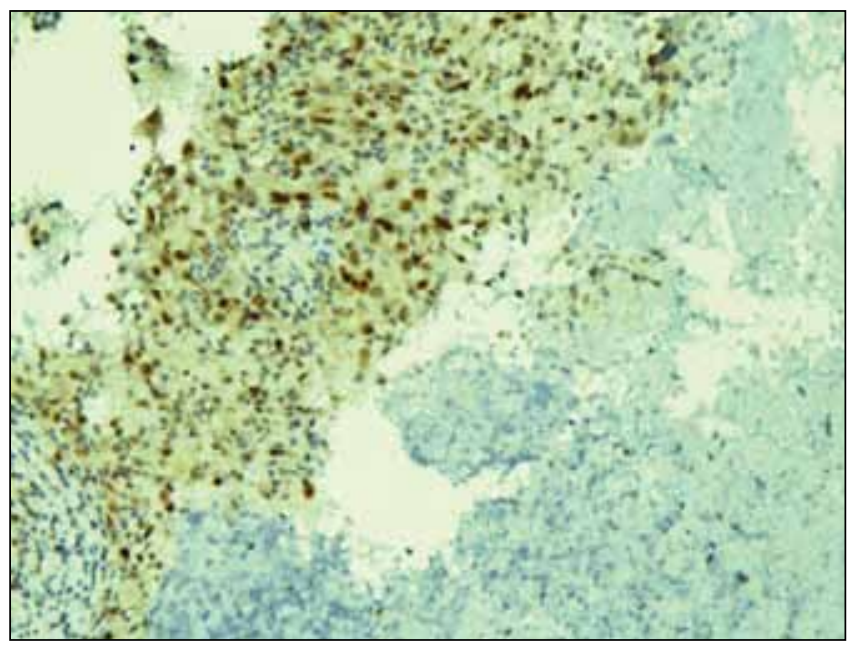

Figure 8 (Case 2): Pseudopalisading necrosis and microvascular proliferation (Hematoxylin and eosinx200).

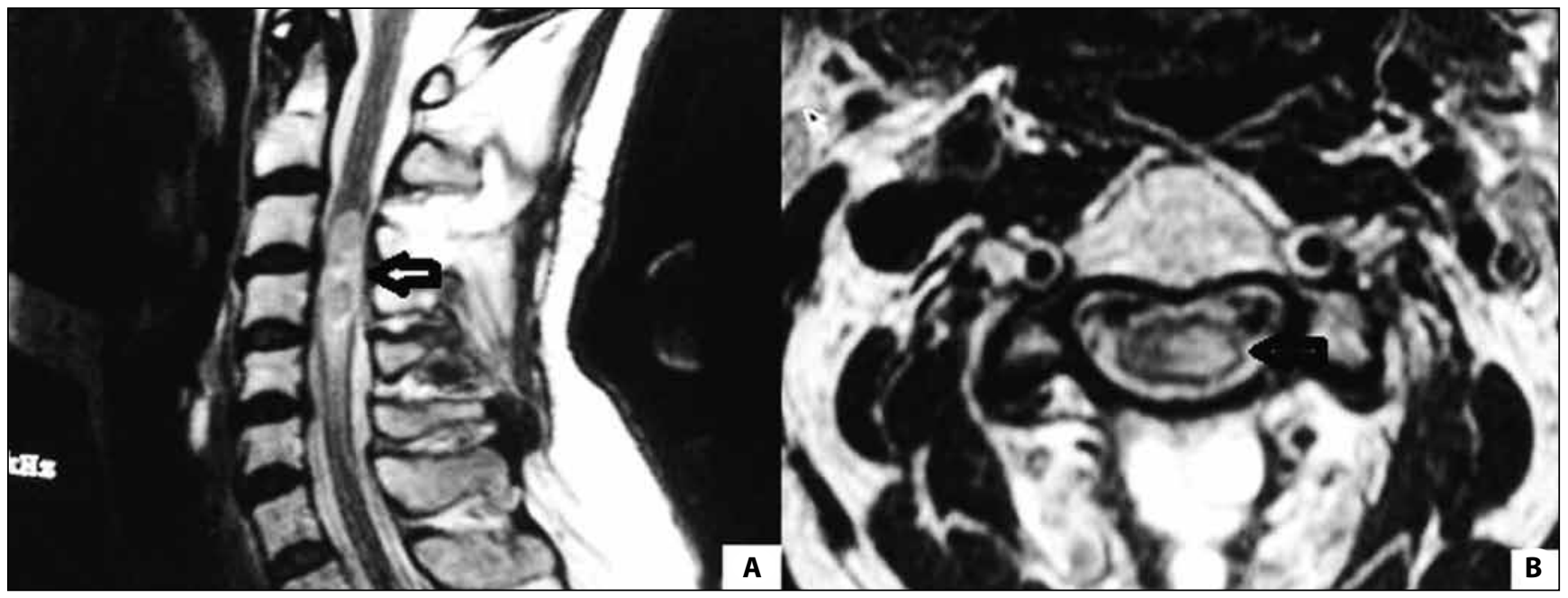

Figure 9 (Case 3): (A) Contrast-enhanced sagittal T1- weighted MRI showing the cervical 3-4 lesion. (B) Axial T1-weighted MRI with contrast showing the intramedullary lesion. 
Table I: Clinical Data in Literature on Intramedullary Glioblastoma

\begin{tabular}{|c|c|c|c|c|c|c|}
\hline Author & & Localization & CSF spread & Treatment & $\begin{array}{c}\text { Survival } \\
\text { month }\end{array}$ & Cause of death \\
\hline O'Connel et al.[17] & $(1)$ & T7-12 & + & Biopsy, Rad. & 4 & Cerebral metastases \\
\hline Tashiro et al.[24] & $(1)$ & Conus & + & Surgery & 11 & Cerebral metastases \\
\hline Andrews et al.[1] & $(1)$ & $\mathrm{T} 12$ & + & Sur., Rad. & 13 & Cerebral metastases \\
\hline Grisold et al.[10] & (1) & $\mathrm{T} 2-4$ & Unknown & Sur., Rad. & $3+$ & Unknown \\
\hline \multirow[t]{3}{*}{ Kopelson et al.[15] } & (1) & Unknown & Unknown & Sur., Rad. & 10 & Cerebral infarctions \\
\hline & $(2)$ & Unknown & Unknown & Sur., Rad. & 18 & Local recurrence \\
\hline & (3) & Unknown & Unknown & Sur., Rad. & 25 & Unknown \\
\hline Takara et al.[23] & $(1)$ & T5-8 & + & Sur., Rad. & 5 & Cerebral metastases \\
\hline Kendrick et al.[14] & $(1)$ & T8-11 & Probable & Sur., Rad. & 1 & Cardiac arrest \\
\hline Rossberg et al.[18] & $(1)$ & T5/6 & Unknown & $\varnothing$ & 1 & Pulmonary embolism \\
\hline \multirow[t]{3}{*}{ Yasui et al.[26] } & $(1)$ & $\mathrm{T} 2$ & Unknown & Sur., Rad. & 64 & Unknown \\
\hline & $(2)$ & C1-T1 & Unknown & Biopsy, Rad. & 6 & Unknown \\
\hline & (3) & T9-12 & Unknown & Surgery & 1 & Unknown \\
\hline \multirow[t]{2}{*}{ Cohen et al.[7] } & $(1)$ & Conus & + & Sur., Rad. & 6 & Cerebral metastases \\
\hline & $(2)$ & Conus & + & Sur., Rad. & 4 & Cerebral metastases \\
\hline Asano et al.[2] & (1) & T11-L1 & + & Sur., Rad. & 12 & Cerebral metastases \\
\hline \multirow[t]{6}{*}{ Ciappetta et al.[6] } & $(1)$ & C3-6 & Unknown & Surgery & 3 & Unknown \\
\hline & $(2)$ & T9 & Unknown & Sur., Rad. & 5 & Unknown \\
\hline & (3) & $C 2-7$ & Unknown & Sur., Rad. & 3 & Unknown \\
\hline & (4) & T7-12 & Unknown & Sur., Rad. & 36 & Unknown \\
\hline & $(5)$ & T1-6 & Unknown & Sur., Rad. & 19 & Unknown \\
\hline & (6) & C3-7 & Unknown & Sur., Rad. & 33 & Unknown \\
\hline Yamazaki et al.[25] & (1) & T9-L1 & $\varnothing$ & Sur., Rad.,Che. & $36+$ & Cerebral\&spinal metastases \\
\hline Kawanishi et al.[13] & $(1)$ & $\mathrm{T} 11-12$ & + & Sur., Rad. & $18+$ & Cerebral metastases \\
\hline Chida et al.[5] & $(1)$ & Diffuse & + & $\varnothing$ & 3 & Cerebral metastases \\
\hline \multirow[t]{2}{*}{ Shirato et al.[20] } & $(1)$ & $\mathrm{T} 11-12$ & + & Sur., Rad.,Che. & 58 & Meningeosis \\
\hline & $(2)$ & $\mathrm{T} 4-8$ & + & Sur., Rad.,Che. & 2 & Meningeosis \\
\hline \multirow[t]{2}{*}{ Iwata et al.[11] } & $(1)$ & Cervical & Unknown & Unknown & 11 & Unknown \\
\hline & $(2)$ & Cervical & Unknown & Unknown & 16 & Unknown \\
\hline Cursiefen et al.[8] & (1) & $\mathrm{C} 5-\mathrm{T} 1$ & + & Sur., Rad.,Che. & 5 & Cerebral metastases \\
\hline Strik et al.[22] & (1) & $\mathrm{T} 11$ & + & Sur., Rad. & 15 & Cerebral metastases \\
\hline Medhkour et al.[16] & $(1)$ & Conus & + & Two sur.,Rad. & 11 & Cerebral\&spinal metastases \\
\hline \multirow[t]{8}{*}{ Banczerowski et al.[3] } & $(1)$ & Conus & Unknown & Biopsy, Rad. & 16 & Unknown \\
\hline & $(2)$ & Thoracic & Unknown & Sur., Rad. & 12 & Unknown \\
\hline & (3) & Cervical & Unknown & Sur., Rad. & 6 & Respiratory arrest \\
\hline & (4) & Conus & Unknown & Surgery & 3 & Paralytic ileus \\
\hline & (5) & Cervical & Unknown & Radiation & 26 & Worse neurological condition \\
\hline & (6) & Conus & Unknown & Sur.,Che. & 10,5 & Worse neurological condition \\
\hline & (7) & Cervical & Unknown & $\varnothing$ & 2 & Respiratory arrest \\
\hline & (8) & Conus & Unknown & Sur., Rad.,Che. & 10 & Residual tumor \\
\hline Bonde et al.[4] & $(1)$ & Diffuse & + & Sur., Rad. & 6 & Quadriplegia \\
\hline \multirow[t]{3}{*}{ Present cases } & (1) & $\mathrm{T} 1-2$ & + & Sur., Rad. & 8 & Brain stem infarction \\
\hline & $(2)$ & $\mathrm{C} 5-\mathrm{T} 2$ & + & Sur., Rad.,Che. & 14 & Sepsis \\
\hline & (3) & C $3-4$ & + & Sur., Rad. & 10 & Cerebral metastases \\
\hline
\end{tabular}

Sur. $=$ Surgery; Rad. $=$ Radiation; Che. $=$ Chemotherapy . 
On histological examination, the tumors were highly cellular and composed of pleomorphic tumor cells with marked nuclear atypia and brisk mitotic activity. Tumor giant cells and gemistocytes were also noted. Vascular endothelial proliferation and necrosis confirmed the diagnosis of glioblastoma. Immunohistochemically GFAP and p53 immunoreactivity was seen in all cases. MIB-1 labeling index ranged from 12 to $34 \%$ (Figures 2-5,7,8).

Only one patient, Case 2, received combined radiotherapy and chemotherapy with steroid therapy following the surgery. The combined therapy was preferred due to the residual tumor. Temozolomide $\left(75 \mathrm{mg} / \mathrm{m}^{2}\right)$ was the drug used during combined therapy. After combined therapy, the same drug continued to be used, but the dose was increased (200 $\mathrm{mg} / \mathrm{m}^{2}$ ).

Only case 2 was able to receive the whole radiotherapy totaling 36 Gy's. Radiotherapy had to be ceased in the other two cases after the very first sessions due to side effects and the poor general condition.

Median survival time from surgery to death was 8.18 months with a range of 2.5 to 14 months. The longest survival time following the operation was 14 months. After surgery neurological status were as follows: Case 1 worsened, Case 2 worsened and Case 3 remained unchanged.

The shortest survival time following the tumor surgery was 2.5 months in the current series. Case 1 died of complications secondary to a brain stem infarction. Case 2, who had 14 months survival time, died due to deficiency of the immune system.

\section{DISCUSSION}

Since primary spinal GBM is a malignant neoplasm, the life expectancy of patients with spinal GBM is quite short, approximately 15 months according to Ciappetta et al. (6) and 9.03 months in this series. The period of time between the onset of the symptoms, the diagnosis, the progressive deterioration and death is less than a year. When the clinical history is longer, it might be related to the low-grade astrocytoma; therefore the diagnosis must be reviewed. In this 3-case series, one of the patients was reported to have hydrocephalous 10 months later following the surgery. The reason for hydrocephalous in primary spinal GBM series is still obscure; however, Cohen et al. (7) have suggested that the increased protein level causes decreased CSF reabsorption.

Spread of tumor cells into the CSF is considered to be the most likely way of the progress of the cranial metastases in spinal GBM (22). They constitute $31.8 \%$ of cases in relevant literature (Table I).

Primary spinal GBM spreading into the CSF is considered to lead to the development of cerebral metastases and carry a very dismal prognosis. The tumor spreads into the CSF and the consequent cerebral metastases pose a fatal threat to the patient's life. Applying radical excision to the tumor is almost impossible in most of the cases due to the lack of cleavage plane between the tumor and the adjacent tissue $(6,27)$.
In the postoperative period, radiotherapy and chemotherapy could be of use; however, due to the small number of spinal GBM cases reported in literature so far, the answer for the question of how effective irradiation and chemotherapy are continues to be a matter of debate $(7,27)$.

\section{CONCLUSION}

As can be seen in the relevant literature, myelogram and CT had been used for the diagnosis of spinal tumors before the advent of MRI $(1,3,6,7,9)$. Valuable data on leptomeningeal involvement and cerebral metastases can be gathered by the MRI technique before and after the surgical operation, and MRI and CSF cytology may be essential for the clinical prognosis of those patients. Proper diagnosis via histopathologic and immunochemical staining with close clinical and radiological follow-up is crucial for the management of spinal GBMs. Therefore, further studies are needed to gain better understanding of the diagnosis and management of spinal GBMs.

\section{REFERENCES}

1. Andrews AA, Enriques L, Renaudin J, Tomiyasu U: Spinal intramedullary glioblastoma with intracranial seeding. Report of a case. Arch Neurol 35(4): 244-245, 1978

2. Asano N, Kitamura K, Seo Y, Mukai K, Soga T, Hondo H, Matsumoto K: Spinal cord glioblastoma multiforme with intracranial dissemination. Report of a case. Neurol Med. Chir Tokyo 30: 489-494, 1990

3. Banczerowski P, Simó† M, Sipos L, Slowik F, Benoist G, Veres R: Primary intramedullary glioblastoma multiforme of the spinal cord: Report of eight cases. Clin Neurosci / Ideggy Szle 56 (1-2): 28-32, 2003

4. BondeV, Balasubramanian S, Goel A: Glioblastoma multiforme of the conus medullaris with holocordal spread. Journal of Clinical Neuroscience 15: 601-603, 2008

5. Chida K, Konno H, Sahara M, Takase S: Meningeal seeding of spinal cord glioblastoma multiforme without any signs of myelopathy. Rinsho Shinkeigaku 35:1235-1240, 1995

6. Ciapetta P, Salvati M, Capoccia G, Artico M, Raco A, Fortuna A: Spinal glioblastomas: Report of seven cases and review of the literature. Neurosurgery 28: 302-6.3,1991

7. Cohen AR, Wisoff JH, Allen JC, Epstein F: Malignant astrocytomas of the spinal cord. J Neurosurg 70: 50-54, 1989

8. Cursiefen S, Sommer C, Behr R, et al: Intramedullary glioblastoma multiforme with spinal intracranial seeding. J Neurol 488, 1998

9. Fortuna A, Giuffre R: Intramedullary glioblastoma. Neurochirurgia (Stuttg) 14: 14-23, 1971

10. Grisold W, Pernetzky G, Jellinger K: Giant-cell glioblastoma of the thoracic cord. Acta Neurochir 58: 121-126, 1981

11. Iwata K, Nakagawa $H$, Hashizume Y: Significance of MIB1, PCNA indices, and p53 protein over-expression in intramedullary tumors of the spinal cord. Noshuyo Byori 13: 73-78, 1996 
12. Johnson DL, Schwarz S: Intracranial metastases from malignant spinal-cord astrocytoma. J Neurosurg 66: 621-625, 1987

13. Kawanishi $M$, Kuroiwa $T$, Nagasawa $S$, Ohta $T$, Oketa $M$, Onomura T: A case of spinal glioblastoma with intracranial dissemination. No Shinkei Geka 21: 1109-1112,1993

14. Kendrick FD, Bonnin JM, Garcia JH: Metastases of a spinal glioblastoma multiforme into an intracranial arachnoid cyst. Neurosurgery 20: 780-783, 1987

15. Kopelson G, Linggood RM: Intramedullary spinal cord astrocytoma versus glioblastoma: The prognostic importance of histologic grade. Cancer 50: 732-735, 1982

16. Medhkour A, Chan M: Extremely rare glioblastoma multiforme of the conus Medullaris with holocord and brain stem metastases, leading to cranial nevre deficit and respiratory failure: A case report and review ot the literature. Surgical Neurology 63: 576-583, 2005

17. O'Connell JEA: The subarachnoid dissemination of spinal tumors. J Neurol Neurosurg Psychiatry 9: 55-62, 1946

18. Rossberg C, Litzenberger J: Intramedullary glioblastoma multiforme with unusual, intracranial neoplastic meningeosis. Nervenarzt 59: 401-404, 1988

19. Russel DS, Rubinstein LJ: Pathology of tumors of the nervous system. London: Edward Arnold, 1989:219-247
20. Shirato H, Kamada T, Hida K, Koyanagi I, Iwasaki Y, Miyasaka K, Abe $\mathrm{H}$ : The role of radiotherapy in the management of spinal cord glioma. Int J Radiat Oncol Biol Phys 33: 323-328, 1995

21. Simeone F: Intradural tumours. Rothman RH, Simeone FAWB. (eds) The spine (3rd edition). Saunders Co, 1992: 1515-1528

22. Strik HM, Effenberger $O$, Schäfer $O$, Risch U, Wickboldt J, Meyermann R: A case of spinal glioblastoma multiforme: Immunohistochemical study and review of the literature. Journal of Neuro-Oncology 50(3):239-243, 2000

23. Takara $E$, Ide $M$, Yamamoto $M$, Imanaga $H$, Jimbo $M$, Imai $M$ : Case of intracranial and spinal dissemination of primary spinal glioma. No Shinkei Geka 13: 301-305, 1985

24. Tashiro K, Tachibana S, Tsuru M: Spinal cord tumor with probable intracranial dissemination, presenting akinetic mutism. No To Shinkei 28:1311-1318, 1976

25. Yamazaki M, Ikota T, Ohkata N, Tashirao T, Sawamura Y, Iwasaki $\mathrm{Y}$, Abe H: A case of spinal cord glioblastoma multiforme. No Shinkei Geka 20: 85-89, 1992

26. Yasui T, Hakuba A, Katsuyama J, Nishimura S: Microsurgical removal of intramedullary spinal cord tumours: Report of 22 cases. Acta Neurochir Suppl Wien 43: 9-12, 1988

27. Zileli M, Coskun E, Ozdamar N, Ovul I, Tuncbay E, Oner K, Oktar $\mathrm{N}$. Surgery of intramedullary spinal cord tumors. Eur Spine J 5:243-250, 1996 